\title{
Phenology and nurse plant of Sotoa confusa (Garay) Salazar (Orchidaceae) in the Southern Potosino Zacatecano Highlands
}

\section{Fenología y nodrizaje de Sotoa confusa (Garay) Salazar (Orchidaceae) en el Sur del Altiplano Potosino Zacatecano}

MUÑOZ-URIAS, Alejandro*†, URIBE-MÚ, Claudia Aurora, HUERTA-MARTINEZ, Francisco Martín and NERI-LUNA, Cecilia

\begin{abstract}
Laboratorio de Evolución de Sistemas Ecológicos, Departamento de Ecología, CUCBA, Universidad de Guadalajara, Camino Ing. Ramón Padilla Sánchez No. 2100, C. P. 45110.Zapopan, Jalisco, México.
\end{abstract}

ID $1^{\text {st }}$ Author: Alejandro, Muñoz-Urias / ORC ID: 0000-0003-0828-9729

ID $1^{\text {st }}$ Coauthor: Claudia Aurora, Uribe-Mú / ORC ID: 0000-0003-1781-0301

ID $2^{\text {nd }}$ Coauthor: Francisco Martín, Huerta Martínez / ORC ID: 0000-0001-6923-3425

ID $3^{\text {rd }}$ Coauthor: Cecilia, Neri-Luna / ORC ID: 0000-0002-8941-2305

DOI: $10.35429 / J U R R E .2019 .5 .3 .13 .17$

Received July 01, 2019; Accepted November 10, 2019

\begin{abstract}
Sotoa confusa is a little conspicuous terrestrial orchid that is distributed in arid and semi-arid land of Mexico and south of USA, its life history is poorly known, so phenology and interaction of this species with shrubs was studied; its bloom occurs in March and fructifies in April (the driest period of the year), latter, from July to September it develops leaves, which disappear in October, so this orchid remains eight months without leaves. By other hand, S. confusa does not grow in areas with bare soil, so it shows preference to grow under the canopy of plants such as Dodonaea viscosa, Opuntia imbricata, $O$. robusta, $O$. leucotricha and Pittocaulon praecox; however, it shows a negative association with Jatropha dioica. The survival strategy of this plant in arid environments is to grow under the canopy of other plants that provide a favorable microclimate and develop leaves only during rainy seasons.
\end{abstract}

Nurse plant, Orchids, Semiarid lands

\begin{abstract}
Resumen
Sotoa confusa es una orquídea terrestre poco conspicua que se distribuye en zonas áridas y semiáridas de México y sur de Estados Unidos de Norteamérica, su historia de vida es poco conocida, por lo cual se estudió la fenología y la interacción del nodrizaje de esta especie con arbustos; florece en marzo y fructifica en abril (el periodo más seco del año), después de esta etapa, de julio a septiembre desarrolla hojas, las cuales desaparecen a partir de octubre, por lo que esta orquídea permanece ocho meses sin hojas. Por otro lado, S. confusa no crece en áreas con suelo desnudo por lo que muestra preferencia a crecer bajo el dosel de plantas como Dodonaea viscosa, Opuntia imbricata, O. robusta, O. leucotricha y Pittocaulon praecox; sin embargo, muestra una asociación negativa con Jatropha dioica. La estrategia de sobrevivencia de esta planta a los ambientes áridos consiste en crecer bajo el dosel de otras plantas que le proporcionan un microclima favorable y solo desarrollan hojas durante temporal de lluvias.
\end{abstract}

Nodrizaje, Orquídeas, Zonas semiáridas

Citation: MUÑOZ-URIAS, Alejandro, URIBE-MÚ, Claudia Aurora, HUERTA-MARTINEZ, Francisco Martín and NERILUNA, Cecilia. Phenology and nurse plant of Sotoa confusa (Garay) Salazar (Orchidaceae) in the Southern Potosino Zacatecano Highlands. Journal-Urban-Rural and Regional Economy. 2019. 3-5: 13-17

\footnotetext{
* Correspondence to Author (email: alejandro.munozu@academicos.udg.mx)

$\dagger$ Researcher contributing as first author.
} 


\section{Introduction}

The Orchidaceae family is characterized by two biotic interactions in particular, pollination and mycorrhizal symbiosis, there are numerous works that describe them (Waterman and Bidartondo, 2008). The pollination of this group was first studied by Darwin; At present, there are numerous records including highly specialized interactions (Waterman and Bidartondo, 2008; Micheneau et al., 2009; Gaskett, 2011). On the other hand, the importance of mycorrhizal associations during germination or growth has been reported (Waterman and Bidartondo, 2008; Rasmussen and Rasmussen, 2009; Jacquemyn et al., 2015). Other aspects of the life history of orchids are poorly known, for example, phenology and nodrizaje (Weston et al., 2005).

Nourishment or facilitation syndrome is a frequent association in arid areas in which some plant species favor the establishment and survival of juvenile stages belonging to other plant species, through the generation of less stressful conditions under their canopy (Fllner and Shmida, nineteen eighty one). The microenvironment provides less solar radiation and greater water availability, therefore it is cooler during warm days in addition to protecting the seedlings from soft frost. The soil under the canopies is less compact, the erosion rate is lower, it can contain more nutrients and in some cases it is usually more humid (Flores and Jurado, 2003). This association has been considered of great importance to model the structure of plant communities in arid areas (Nobel, 1988).

Phenology is one of the most important characteristics in the life cycle of plants, phenological events or phenophases are influenced by climatic conditions and biotic interactions with other organisms such as the selection pressure exerted by their pollinators, their herbivores and the dispersers of its fruits and seeds (Thomson, 1980; Ratchke and Lacey, 1985). This terrestrial orchid inhabits semi-arid regions, dry pine and oak forests, juniper and oak forests, deciduous tropical forests, in various types of xerophilous shrubs, induced grasslands or degraded areas of these plant associations (Hágsater et al., 2005; Salazar et al., 2006; Peinado and Riojas 2008; Salazar, 2009). The objective of this study was to determine the noduization of the confusing Sotoa terrestrial orchid and to document some preliminary aspects related to its phenology.

\section{Methodology}

Sotoa confusa (previously described as Deiregyne confused by Leslie A. Garay in 1982) (Salazar and Ballesteros-Barrera, 2010) (fig. 1), is an orchid of terrestrial habits. It is distributed in the southern United States (Texas), and in Mexico it has been registered in Coahuila, Federal District, Durango, State of Mexico, Guanajuato, Hidalgo, Jalisco, Michoacán, Nuevo León, Northern Oaxaca, Puebla and San Luis Potosí (Peinado and Riojas, 2008). The specimens from the study area were determined by specialists from the Botany Institute of the University of Guadalajara based on the descriptions of Salazar and Ballesteros-Barrera (2010). The material was deposited in the Herbarium "Luz María Villarreal de Puga" (IBUG) of the University of Guadalajara.

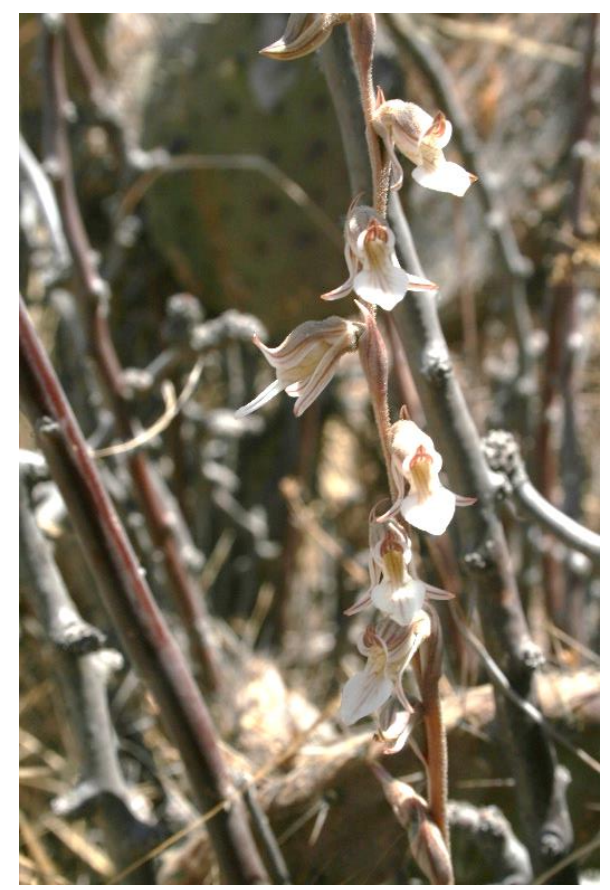

Figure 1 Sotoa confused in bloom

This study was carried out in the Llanos de Ojuelos region, in the semi-arid plateau of the southwest part of the Chihuahuan Desert. The annual rainfall is $542 \mathrm{~mm}$, while the average annual temperature is $16.65^{\circ} \mathrm{C}$. The climate is classified as temperate dry steppe in the Köppen system (fig. 2). The study area is a rocky outcrop, characterized by the presence of Yucca descipiens, Ferocactus histrix, Phytocaulon praecox, Asclepias linnaria, Opuntia robusta, Opuntia cantabrigiensis, Mimosa biuncifera among others). 


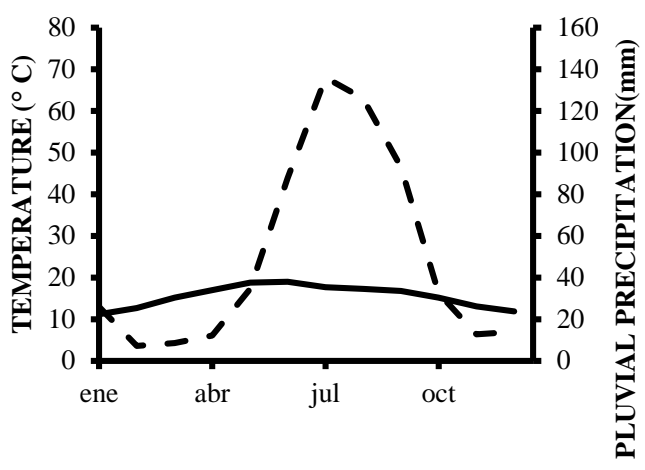

- temperatura promedio - - Precipitación pluvial

Figure 2 Climate graph of the study area

In the town we found a confusing Sotoa population, in which 51 individuals were marked. The development of the peduncle, fruiting, presence and senescence of leaves was recorded every month for a year.

In order to determine the noduization relationship of S. confusa with other species, the relative vegetation coverage was calculated, by means of eight circular plots of $900 \mathrm{~m} 2$, additionally the frequency of $\mathrm{S}$. confused growing under each species was recorded. hypothesis that this is distributed uniformly under the canopy of the plants, weighting the relative coverage of each species, by means of a test of goodness of fit of X2, subsequently Pearson's standardized residuals were compared to identify positive associations and negatives between S. confusa and other species (Everitt, 1977).

\section{Results}

The phenological record of this species shows that flowering occurs in the month of March and ends in April, during which time it develops several flowers in the spine that open asynchronously, each flower can last more than four days. The phenological record of this species showed that the leaves and flowers developed in different periods of the year. Flowering occurred during the months of March and April, during which time he developed flowers in the spine, these opened asynchronously, each flower lasted up to four days. It fructified in April. The foliar expansion was carried out in the second half of the rainy season (August to October), the leaves showed evidence of senescence and died from the month of November (fig. 3).

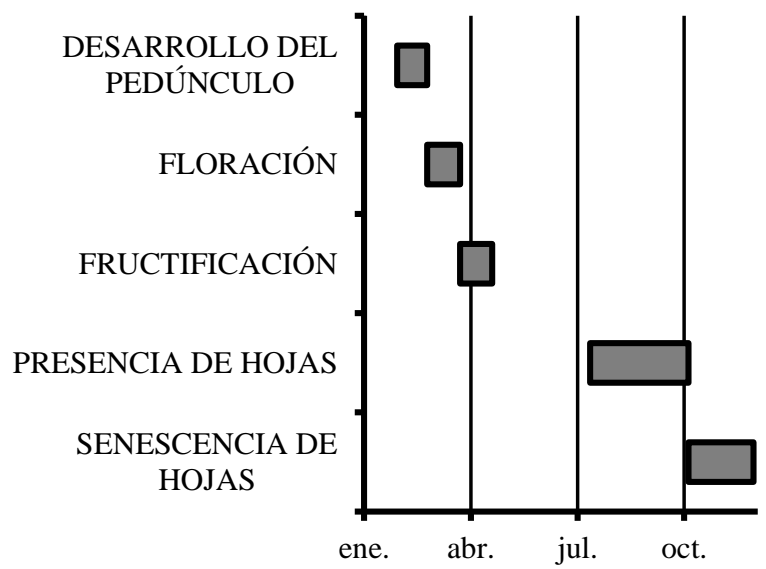

Figure 3 Sotoa confused phenology in the southern portion of the Potosino-Zacatecano highlands

The vegetation samples of the rocky outcrop show 26 species of plants among which the species Yucca decipiens, Ferocactus latispinus, Dasylirion acrotriche stand out, however the most abundant are listed in Table 1.

\begin{tabular}{|l|r|}
\hline \multicolumn{1}{|c|}{ Species } & Relative coverage \\
\hline Jatropha dioica & 0.370 \\
\hline Opuntia streptacanha & 0.106 \\
\hline Opuntia leucotricha & 0.084 \\
\hline Robust opuntia & 0.075 \\
\hline Happlopapus venetus & 0.070 \\
\hline Mimosa Biuncifera & 0.066 \\
\hline Opuntia xoconostle & 0.047 \\
\hline Pittocaulon praecox & 0.011 \\
\hline Opuntia imbricata & 0.006 \\
\hline Dodonaea viscose & 0.002 \\
\hline
\end{tabular}

Tabla 1 Species with greater relative coverage in rocky outcrops in the southern portion of the Potosino Zacatecano Altiplano

Four individuals of S. confused per hectare were registered. Two individuals grew up in the shadow of the rocks and 49 in patches of vegetation. Of these, 40 organisms $(81.6 \%)$ were under the canopy of Opuntia imbricata, $\mathrm{O}$. leucotricha, O. robusta, O. streptacantha and $\mathrm{O}$. xoconostle. The remaining nine orchids (18.4\%) were located under the canopies of Happlopapus venetus, Jatropha dioica, Mimosa biuncifera, or Pittocaulon praecox; No plants were found growing in vegetation clearings exposed to direct solar radiation. We found statistically significant differences between a uniform distribution pattern weighted with coverage (X2 $=1069.6, \mathrm{P}<0.001)$. The analysis of adjusted residuals showed that $S$. confusa is significantly and positively associated with Opuntia imbricata, O. robusta, O. leucotricha and Pittocaulon praecox, while the association was negative with Jatropha dioica (fig. 4).

MUÑOZ-URIAS, Alejandro, URIBE-MÚ, Claudia Aurora, HUERTAMARTINEZ, Francisco Martín and NERI-LUNA, Cecilia. Phenology and nurse plant of Sotoa confusa (Garay) Salazar (Orchidaceae) in the Southern Potosino Zacatecano Highlands. Journal-Urban-Rural and Regional Economy. 2019 


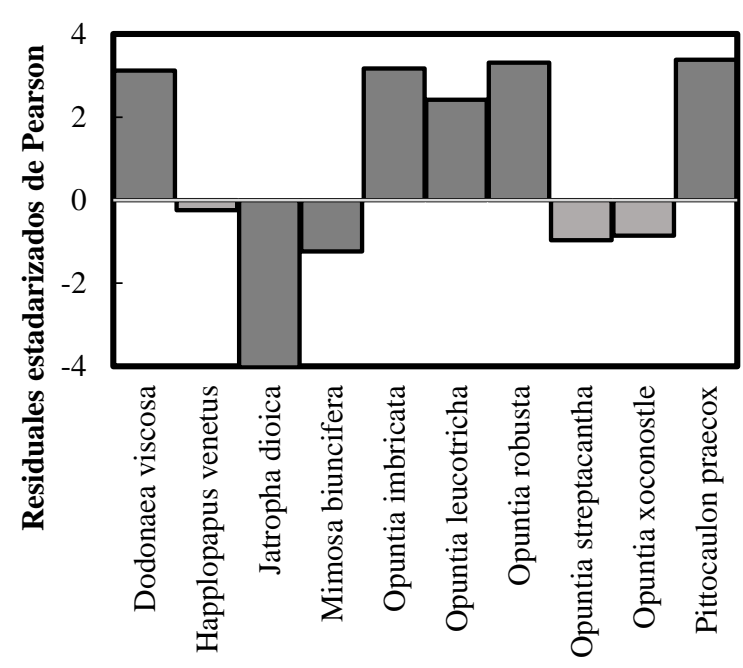

Figure 4 Analysis of Pearson's standardized residuals, (light gray bars do not show statistical significance)

\section{Discussion}

The results showed that S. confusa was found preferentially in patches of vegetation under the canopy of plants and in a smaller amount under the shade of rocks, which indicates that this species may require nurses to favor its survival, as reported for other species in this environment (García-Moya and McKell, 1970; Jordan and Nobel, 1981; Valiente-Banuet and Ezcurra 1991). For the Orchidaceae family, facilitation has only been documented in the Australian species Caladenia behrii where there is a positive association with vegetation (wetting) when the kangaroo herbivory pressure is high (Petit and Dickson, 2005; Weston et al., 2005) .

In this study, we found foliar damage in S. confused caused only by invertebrates despite the fact that there are herbivorous mammals in the area, therefore, we do not have evidence that indicates the decrease in herbivory by the nodrizaje.

In the months of January to May, during the reproductive phase of $\mathrm{S}$. confusa, most of the plants that make up the vegetation patches were devoid of leaves. However, Opuntia spp. and Pittocaulon praecox provided shade because $S$. confusa plants are located adjacent to the cladodes and succulent stems of both species without hindering the location of flowers by pollinators.
The vegetative phase of $\mathrm{S}$. confusa, develops during the months of July to October, coincided with the rainy season, the rainfall for this period was $257 \mathrm{~mm}$ (42\% of the annual rainfall) most of the plants that make up The patches of vegetation presented leaves, S. confused could receive less solar radiation because it is under the canopy of the bushes, however, noduization would allow this species to reduce light stress and perform photosynthesis efficiently. Some studies that have evaluated the photosynthesis of terrestrial orchids under the canopy have shown that this group is efficient in capturing light, for example, Arundina graminifolia and Spathoglottis plicata, species with light saturation points of $200 \mu \mathrm{mol} \mathrm{m}-2 \mathrm{~s}-1$ (Hew and Yong, 2004).

Although our phenological data correspond only to one year and should be taken with caution, because they may be influenced by interannual environmental variations; The flowering pattern of S. confusa coincided with the descriptions made by Sahagún-Godínez (1996) for numerous species of orchids belonging to the Spiranthinae subtribe. This fact suggests that the phenological pattern is given by a combination of ecological and evolutionary effects, and not just environmental factors.

The Orchidaceae family is cosmopolitan, although they are more abundant in tropical and temperate environments unlike dry or semi-dry areas (Correll, 1978), where limiting factors such as lack of water and excessive solar radiation can limit their distribution; Under these conditions, the phenology and interactions such as nodrizaje attenuate these factors. This study constitutes the first record for this orchid in the state of Zacatecas and the presence of this interaction for orchids in arid areas of the Americas.

\section{References}

Correll, D.S. (1978). Native Orchids of North America North of Mexico. Stanford University Press. United States of America 416 pp.

Everitt, B.S. (1977). The analysis of contingency tables. Chapman and Hall, New York 164 pp.

Fllner, S. \& Shmida A. (1981). Why are adaptations for long range seed dispersal rare in desert plants? Oecologia, 51(1), 133-144. 
Flores, J. \& Jurado E. (2003). Are nurse-protégé interactions more common among plants from arid environments? Journal of Vegetation Science, 14(6), 911-916.

García-Moya, E. \& McKell, C.M. (1970). Contribution of shrubs to the nitrogen economy of a desert-wash community. Ecology, 51(1), 8188.

Gaskett, A. C. (2011). Orchid pollination by sexual deception: Pollinator perspectives. Biological Reviews, 86, 33-75.

Hágsater, E., Soto-Arenas, M.A., SalazarChávez, G.A., Jiménez-Machorro, R., LópezRosas, M.A. \& Dressler, R.L. (2005). Orchids of Mexico. Instituto Chinoín, México 304 pp.

Hew, C.S. \& Yong, W.H. (2004). The physiology of tropical orchids in relation to the industry. Ed. World Scientific Publishing Co, Singapore. 370 pp.

Jacquemyn, H., Brys, R., Waud, M., Busschaert, P., \& Lievens, B. (2015). Mycorrhizal networks and coexistence in species-rich orchid communities. New Phytologist, 206, 1127-1134

Jordan, W.P. \& Nobel. P.S. (1981). Seedling establishment of Ferocactus acanthodes in relation to drought. Ecology, 62(4), 901-906.

Micheneau, C., Johnson, S.D., \& Fay, M.F. (2009). Orchid pollination: from Darwin to the present day. Botanical Journal of the Linnean Society, 161(1), 1-19.

Nobel, P.S. 1988. Environmental Biology of Agaves and Cacti. Cambridge University Press, Cambridge, United Kingdown. 270 pp.

Peinado, M. \& Riojas, M. 2008. Primer registro de Deiregyne confusa para Jalisco, México. Boletín de la Sociedad Botánica de México, 82, 67-68.

Petit, S. \& Dickson, C.R. (2005). Grass-tree (Xanthorrhoea semiplana, Liliaceae) facilitation of endangered pink lipped spider orchid (Caladenia syn. Arachnorchis behrii, Orchidaceae) varies in South Australia. Australian Journal of Botany, 53(5), 455-464.

Rasmussen, H. N., y Rasmussen, F.N. (2009). Orchid mycorrhiza: Implications of a mycophagous life style. Oikos, 118, 334-345.

ISSN-On Line: 2524-2083

RINOE® All rights reserved
Ratchke, B. \& Lacey, E.P. (1985). Phenological patterns of terrestrial plants. Annual Review of Ecology and Systematics, 16,179-214.

Sahagún-Godínez, E. (1996). Trends in the phenology of flowering in the orchidaceae of western Mexico. Biotropica, 28(1), 130-136.

Salazar, G.A., Reyes-Santiago, J., Brachet, C. \& Pérez-Crisanto, J. (2006). Orquídeas y Otras Plantas Nativas de la Cañada, Cuicatlán, Oaxaca. México. Instituto de Biología, Universidad Nacional Autónoma de México, Fundación para la Reserva de la Biosfera Cuicatlán A.C., Sociedad Mexicana de Cactología A.C. y Comisión Federal de Electricidad. México. 175 pp.

Salazar, G. A. (2009). Orquídeas. En: Lot, A. \& Cano-Santana, Z. (eds.) Biodiversidad del Ecosistema Reserva Ecológica del Pedregal de San Ángel, pp. 153-169. Universidad Nacional Autónoma de México, México.

Salazar, G.A. \& Ballesteros-Barrera, C. (2010). Sotoa, a new genus of Spiranthinae (Orchidaceae) from Mexico and the southern United States. Lankesteriana, 9(3), 491-504.

Thomson, J. D. (1980). Skewed flowering distributions and pollinator attraction. Ecology, 6(3), 572-579.

Valiente-Banuet, A. \& Ezcurra, E. (1991). Shade as a cause of the association between the cactus Neobuxbaumia tetetzo and the nurse-plant Mimosa luisana in the Tehuacan Valley, Mexico. Journal of Ecology, 79(4), 961-971.

Waterman R.J. \& Bidartondo, M.I. (2008). Deception above, deception below: linking pollination and mycorrhizal biology of orchids. Journal of Experimental Botany, 59(5), 10851096.

Weston, P.H., Perkins, A.J. \& Entwisle, T.J. (2005). More than symbioses: orchid ecology, with examples from the Sydney Region. Cunninghamia, 9(1), 1-15. 